\title{
HUMANITARIAN INTERVENTION. SELECTED ASPECTS ${ }^{1}$
}

With the development of human rights agenda in the last century, the world has entered the era of responsibility of international community for the safety of the people. Simultaneously, deepening economic, ethnic and cultural divisions that are observed in the last decades, lead to conflict, that are new both in their brutality, targeting the civilians as well as socio-political complexity. Having developed amazing communication possibilities as well as great mobilisation of civil society, the world cannot ignore the atrocities that are still happening. World leaders developed a concept of humanitarian intervention, which should help to react on this kind of necessity. However, as great and essential the idea of humanitarian intervention is, it face a lot of controversy and difficulties. The following essay will present the complexity if the idea and the challenges it brings.

\section{DEFINITION AND CHARACTERISTICS OF HUMANITARIAN INTERVENTION}

Concept of humanitarian intervention has changed over the last century in accordance to the changing international environment. As the issue of humanitarian intervention is related to many fields of activities and interests like international law, political science, morality and ethics, or international relations, there exist many definitions of the idea.

Adam Roberts defines humanitarian intervention as "military intervention in a state, without the approval of its authorities, and with the purpose of preventing widespread suffering or death among the inhabitants" (Roberts, 1993: 429). In the words of Tony Brems Kundsen humanitarian intervention is "dictatorial or coercive interference in the sphere of jurisdiction of a sovereign state motivated or legitimated by humanitarian concerns" (Kundsen, 1997: 146). According to J. L. Holzgrefe humanitarian intervention is "the threat or use of force across state borders by a state (or group of states) aimed at preventing or ending widespread and grave violations of the fundamental human rights of individuals other than its own citizens, without the permission of the state within whose territory force is applied" (Holzgrefe, 2003:18).

Despite the different perspectives and backgrounds there are some common points that can be found in many definitions. According to Saban Kardas there are four typical

1 All views presented in the article are personal assessments of the author, and do not represent any official statement of any organization. 
characteristics in defining humanitarian intervention: use of military force, the absence of the target state's permission, what distinguishes it from peacekeeping, the aim to help non-nationals as well as agency of intervention ${ }^{2}$ (Kardas, 2001:2).

Michael J. Mazarr distinguishes two types of humanitarian interventions with different roles for the military actors in field. One would involve the delivery of food, medicine and shelter in a kind environment - in response, for example, to a natural disaster. In such cases the role of the military would consist in organising transportation, providing discipline and order in unstable situation, as well as in deploying medical and engineer units. In general, in this kind of humanitarian interventions the role of the military is limited to logistics, rather than usage of force. Second types are the humanitarian crises that are symptom of deeper political and social problems. In these cases humanitarian interventions involve hostilities or threat of them (Mazarr, 1993: 152-153).

In fact, as many scholars emphasize, one of the characteristic of the military intervention for human protection purposes is the hostile environment, where the political order is questioned and the national authorities do not have the capacity or the will to respond to the basic needs of people for safety, shelter, food, water or medical services. It is also the dimension of humanitarian intervention, on which this essay will concentrate.

Modern humanitarian intervention, as evolved through the last decades poses important characteristics, which influence the relations between civil and military parties involved in action. An effective humanitarian intervention is one that saves lives by preventing or ending violent conflicts on civilians, or by assisting the delivery of aid, or both. As Taylor B. Seybolt describes "humanitarian intervention is a short-term activity with limited political objectives." (Seybolt, 2007: 6). It is intended to stop the worst suffering and not to establish a lasting peace or to put a new political system in place. This is the other factor that distinguishes such efforts from peacekeeping, whose main goal is monitoring political and military actors. However, humanitarian intervention can establish a ground for peace-building, by creating safer environment in which people can think beyond the concerns about their survival. Accordingly, humanitarian intervention is not meant directly to protect or promote civil and political rights, but rather to protect fundamental human rights in extreme circumstances.

\section{DEVELOPMENT OF THE CONCEPT THROUGHOUT THE HISTORY}

Humanitarian intervention is not a new concept. However, it has changed over time in some systematic and important ways. The early debates about the concept can be tracked back to $16^{\text {th }}$ and $17^{\text {th }}$ century classical writers on international law. However, apart from these intellectual precursors, the modern concept of humanitarian intervention is generally associated with state practise in $19^{\text {th }}$ century, when states started to invoke humanitarian reasons to justify their interventions. ${ }^{3}$

2 Though some confine the term to interventions by states on their own (self-help), there is a recent tendency to include interventions under UN umbrella.

${ }^{3}$ For more information about the history of early humanitarian interventions please refer to: Martha Finnemore, Constructing Norms of Humanitarian Intervention, in: The Culture of National Secu- 
First legal basis for international human relief, were the Hague Conventions, as well as the four Geneva Conventions of 1949, which became the core of International Humanitarian Law. These norms were later included in several articles of the UN Charter, that obligate governments to protect their citizens. Moreover, UN Charter introduced a new interpretation of use of force in international relations. First, it affirmed and extended the doctrine of non-intervention to all states and made it a universal norm. Second, in Chapter VII of the Charter, it allowed to use force only in case of self-defence or collective security measures in case of the threat to international peace and security. Additionally, all act of intervention became the subject to authorisation by the UN, acting as the representative of the international community (Kardas, 2001: 3).

Along with the above developments, UN initiated the promotion of human rights as a global issue, which during the years of Cold War remained in conflict, or incompatible with the norms of state sovereignty and non-intervention. Only after the end of rivalry of the two superpowers the norms relating to the protection of rights of individuals have increasingly received general acceptance, especially among the Western states. As Kapil Kak describes "the end of the Cold War has witnessed an increasing trend towards willingness of states to intervene militarily in the internal affairs of other states, ostensibly in response to civil war conditions, gross human rights violations or ethnic cleansing" (Kak, 2008: 1235).

The following 1990s became the decade of humanitarian intervention. With the break-up of various Cold War state structures, one of the main problems became that of intrastate conflict, civil war, and internal violence perpetrated on massive scale. The number of interventions authorised by UN Security Council increased dramatically and it became clear, that state sovereignty and non-intervention principle were far from inviolable. High hopes and expectations of international community of ending massive human rights abuses, large scale massacres or genocides through UN intervention shaped UN decisions and actions. However, the first UN's failures in Bosnia, Somalia and Rwanda did not bring expected results and satisfaction. The situation in Kosovo in 1999, when the international community represented by NATO did in fact intervene, but did so without the authority of the Security Council, was another point that generated debate about humanitarian intervention. As Independent International Commission on Kosovo described the action - it was "legitimate, but not legal" (Evans, 2006: 706-707).

These events led UN Secretary General Kofi Annan to agitate to the General Assembly in 2000, presenting the view, that "if humanitarian intervention is, indeed, an unacceptable assault on sovereignty, how should we respond to a Rwanda, to a Srebrenica - to gross and systematic violations of human rights?" (Millenium, 2000: 48).

Adele Brown asserts, "Kosovo in many respects was a defining moment in the debate over how, when and even if international community should protect people facing humanitarian crises within a sovereign state" (Brown, 2008: 12). 
The defining moment in the debate was a report prepared in 2000 by International Commission on Intervention and State Sovereignty (ICISS) - Responsibility to Protect. The first main contribution of the commission was redefining the concept of state sovereignty, which should be understand not as a power or control - as it was mostly perceived so far, but rather as a state responsibility to protect its own citizens. The second was an invention of a new way of thinking about humanitarian intervention. Commission turned the debate about the right to intervene in a way of re-characterizing it from an argument about right, into argument about responsibility. The third contribution was the emphasis on the fact, that responsibility to protect (R2P) was much more than intervention, and in particular military intervention. It included responsibility to prevent, to react and to rebuild (Responsibility, 2001). But as Gareth Evans notices "the question of military action remains, for better or worse, the most prominent and controversial one in the debate" (Evans, 2006: 709). At the World Summit in 2005 the UN General Assembly adopted the principle of the $\mathrm{R}_{2} \mathrm{P}^{4}$ distinguishing three pillars: the protection responsibilities of the state, international assistance and capacity-building as well as timely and decisive response (Implementing, 2009: 2). In the next year, UN Security Council reaffirmed the endorsement of the concept with its Resolution 1674 (Resolution, 2006).

By receiving this official UN confirmation, the R2P became a worldwide accepted principle. In case, when a state is "manifestly failing" to protect its population from genocide, war crimes, ethnic cleansing and crimes against humanity, international community, according to the R2P, should respond collectively in timely and decisive manner, using Chapter VI, VII and VIII of the UN Charter as appropriate. ${ }^{5}$ It is the responsibility of the Security Council to act in timely and decisive manner. If it does not reach a unanimous decision, the liability falls on General Assembly; however, its decisions in such case are not legally binding (United Nations General Assembly, 2009: 22). Humanitarian intervention, according to international law, should be authorized by UN Security Council. However it can also occur without legal authorization. The conditions for legitimacy and legality of civil-military intervention will be described in the following part of the essay.

\section{LEGITIMACY AND LEGALITY OF HUMANITARIAN INTERVENTION}

As responsibility to protect is the most recent and relevant doctrine concerning civil-military humanitarian intervention the following part will mostly concentrate on the legitimacy of the intervention within the framework of this concept.

Responsibility to protect identities five criteria, which should be applied by the Security Council - and use by the world at large - to test the validity of any case made for a coercive humanitarian intervention. The first one is just cause, which is understood as

4 The principle of R2P was adopted in articles 138 and 139 of the World Summit Outcome: United Nations General Assembly, 2005 World Summit Outcome, 2005, p. 31, 20 September 2011, at http://www.who.int/hiv/universalaccess2010/worldsummit.pdf.

${ }^{5}$ Chapter VI: Pacific Settlement Disputes, Chapter VII: Action with Respect to Threats to the Peace, Chapter VIII: Regional Arrangements. United Nations, Charter of the United Nations and the Statute of the International Court of Justice, New York 1945. 
"serious and irreparable harm occurring to human beings, or imminently likely to occur" in form of large scale loss of life, or large scale ethnic cleansing. (International Commission on Intervention and State Sovereignty, 2000: XII). As Evans points out, "the bar for military intervention here has been set deliberately high and tight and excludes many kinds of unconscionable behaviour (e.g., imprisonment and torture of political opponents or overthrow of democratically elected government) that would certainly justify other forms of coercive response (e.g. targeted sanctions)" (Evans, 2006: 710). The following four criteria are: the right intention, which should ensure, that the primary purpose of the proposed military action is to stop or prevent human suffering; last resort, which put emphasis on exploring every non-military option for prevention or peaceful resolution, before deploying the military components; proportional means, that is the adjustment of the scale, duration and intensity of the military action to the minimum necessity, to secure humans in danger; and last but not least - the reasonable prospects, that is the chance for the military action to be successful (International Commission on Intervention and State Sovereignty, 2000: XII). Another issue raised by some academics is multilateralism as a condition necessary for intervention to be legitimate (Finnemore, 1996: 15).

However, even taking into account the above listed rules of legitimate intervention, there remains problem of legality. As Evans points out, "what if, taking into account all five criteria of legitimacy, a very clear case could be made for coercive intervention, but Security Council - under the UN Charter the only source of authority for the use of military force except in cases of legitimate self-defence - simply would not vote to authorize it?" (Evans, 2006: 711). The problem of legality in such cases concentrates around mobilizing the necessary political will, in particular in the Security Council and its permanent members, as it was already the case by Kosovo in 1999, when all elements of horrific new ethnic cleansing operation were failing into place, but Russia made clear it would veto any military action (ibidem: 712). What is more, as Brown claims, for many countries R2P has a moral but not legal force. She describes, that both the British and US Governments have indicated that they regard the R2P as a political commitment and not a legal one (Brown, 2008: 5).

Carsten Stahn, on the other hand raises the question "how can a concept, that is labelled as a 'new approach' and 're-characterisation of sovereignty' in 2001 turn into an emerging legal norm within the course of four years and into an organizing principle for peace and security in the UN system one year later?" (Stahn, 2007: 101).

All these questions are still the issues of political and academic debate, and often can be answered only in reference to particular situations and cases, as every humanitarian intervention is a set of different circumstances and problems.

\section{CIVIL-MILITARY RELATIONS IN HUMANITARIAN INTERVENTION}

Assuming, there is a complete agreement, in some last resort situation, about the legality and legitimacy of military intervention, there remains still the problem of capacity as well as its relations with civilian organisations on field. The question of capacity concerns such issues like the number of personnel and equipment, its flexibility to de- 
ployment, level of training, command, control and communications capability, transportability and general logistic support (Evans, 2006: 719). The problem of civil-military relations in humanitarian interventions is one of the complex issues that remain still under development analysing lessons learned from the interventions in the last decade of $20^{\text {th }}$ century. ${ }^{6}$

Guidelines for civil-military cooperation in field were described in detail in Oslo Guidelines, which focus on the use of military and civil defence assets in disaster relief, (Guidelines, 2006); as well as in Civil-Military Guidelines \& Reference for Complex Emergencies, prepared by Office for the Coordination of Humanitarian Affairs in United Nations (Civil-Military, 2008). These guidelines, provide general rules for interaction between different actors, the way of sharing the tasks as well as the competency and report division. They both underline the core principles of the involvement in humanitarian actions such as humanity, neutrality and impartiality (ibidem: 15; Guidelines, 2006: 7).

Although many of these principles and regulations can and are used in humanitarian interventions, it is also clear, that in case of such emergencies, carried out under international pressure, moral and political dilemmas and often with no clear views about its legality or legitimacy, the joined civil-military action face even more difficulties. The following part will describe some of the most urgent and influential issues that can decide about the success or failure of the operation.

First of all, despite clear division into civil and military actors, neither is monolithic and each represents a set of diverse institutions. ${ }^{7}$ In general, military and civilian actors of humanitarian intervention have common goal of providing human security in societies torn by conflict. Often, they also share the same understanding of the limits of their action, emphasizing that both humanitarian assistance and military intervention are not enough for bringing a solution for political emergencies and war (Slim, 1996: 124).

However, the main factor that design civil-military interactions is not the analysis of long-term goals, but necessity, which is often called "the mother of co-operation" (Gourlay, 2000: 34) Therefore, the most intense civil-military relationships during humanitarian interventions have been formed at the field level. To understand the challenge, potential and limitations of this relationship, it is necessary to describe the fundamental differences of the two sets of institutions.

First important disparity is the politicization of the military, and the fact that it has been traditionally designed for war and to accomplish objectives set by governments using regulated violence. In juxtaposition with neutrality, equality and no political agenda of civil humanitarian organisations, this issue results in inevitable tension between the two actors. In cases when military is perceived by locals as a party to a conflict, civil-military relations become outstripped and hardly cooperative (Weiss, 1995:

${ }^{6}$ In 2000s, there was no humanitarian intervention until the crisis in Lybia in 2011, which was the first case of using the tool of R2P by Security Council.

${ }^{7}$ Military force can vary in size, structure, capability, posture, competence and professionalism. It can also fall under different commands, like UN, NATO or national commands. Civilian humanitarians are usually divided into three main groups: UN agencies, the ICRC and the Red Cross and Red Crescent Movement, and international and national NGOs. 
160). Second are the fundamental difference in structure and working methods of the two actors, with military placing high value on command and control, top-down hierarchical organisational structures and clear lines of authority, discipline and accountability. On the other side humanitarian organisations are less hierarchical and more participatory in their style of decision-making and operations. They are also more focused on long-term impacts and have fewer back-up resources than military.

According to Gourlay, "the distribution of tasks between military and civilian institutions has often proceeded according to the essentially as hoc and fluid concept of 'gap filling' whereby the military takes on tasks for which civilian agencies have no competence or which they cannot fulfil in the short-term." In this sense, the military conduct of civilian tasks, should be handed over to civilian as soon as possible (Gourlay, 2000: 37).

More specifically, military tasks in the humanitarian sphere include controlling violence by bringing down the levels of violence between organized military formations, providing protection for the relief efforts as well as supporting the work of civilian humanitarian agencies by organizing transportation and technical help. The security-related tasks can also involve demining and demobilization (Minear, Guillot, 1996: 82-84).

Another set of tasks carried out by the military is providing direct assistance to those in need, which is often the area of greatest competition between military and civilian actors. Such activities are often perceived by aid agencies as the evidence of the militarization of the humanitarianism. They put into question the competencies of the military to carry out direct-assistance tasks and reproach armed forces with little cost-effectiveness (Gourlay, 2000: 39-40).

\section{CIVIL-MILITARY CO-OPERATION IN HUMANITARIAN INTERVENTIONS}

One of the hardest manageable issues, concerning civil-military relations in humanitarian intervention is its ad hoc approach, which makes the cooperation improvisational and pragmatic, as it was the case in most humanitarian emergencies in 1990s. Although, as some argue, every crisis is different and unique and therefore require different approach, strategies and structures, in the last years there have been attempts to develop structures' and tasks' division for civil-military relation which could be a basis for future humanitarian interventions.

One of such approaches is presented in Civil-Military Co-operation doctrine $(\mathrm{CIMIC})^{8}$ developed by NATO, after many lessons learned in Bosnia and Kosovo in 1990s. Based on these experiences, CIMIC basic tasks are divided into three stages, which will be shortly presented below. First stage is pre-operational and is design to

8 CIMIC is defined as "The co-ordination and co-operation, in support of the mission, between the NATO Commander and civil actors, including national population and local authorities, as well as international, national and non-governmental organisations and agencies." (NATO Civil-Military Co-operation (CIMIC) Doctrine 2003, p. 1-1). 
help to prepare allied force to deal with the civilian conditions. This task includes planning, advice to the chain of command as well as training and educating the force. Second, operational task, is the core of CIMIC task throughout the operation, which include establishing and maintaining relations with a wide range of civil actors. These include communication, co-ordination, exchange of information, setting up of agreements, assessment and operations. Third stage includes transitional tasks which are supposed to smooth transition to the proper mandated authorities and the termination of the military's involvement (NATO Civil-Military, 2000: 3-1-3-3).

Although there is no single solution for managing civil-military relations in humanitarian interventions, yet, as Gourlay asserts, "if humanitarian operations are to improve, we need to structure and learn from each operational experiment more systematically. It is only in this way that operations will be able to build on past experiences and lessons learned by different actors" (Gourlay, 2000: 44).

\section{LESSONS LEARNED FROM KOSOVO}

Kosovo operation in 1999 was one of the latest and most significant humanitarian interventions having influence on later development of the legal and civil-military cooperation doctrines. It started quite controversial, as there was no clear legal Security Council authorisation for the member states' armed force to intervene. Politically, NATO full-scale operation against Yugoslavia was based on an implied right of humanitarian intervention given the fact, that the UN Security Council had previously defined the situation as a threat to international peace and security (Kardas, 2001: 6). Therefore the question about legality and legitimacy of the intervention was fueling the debate in the following years. As mentioned above, case of Kosovo intervention is nowadays perceived as an intervention that was not legal but legitimate. ${ }^{9}$

Another issue concerns civil-military cooperation. One of the main characteristics of the complexity of the mission was the number of distinct components which composed it. Operation composed of KFOR, the NATO military mission, consisted of contingents from member states; UNMIK, civilian UN Mission in Kosovo ${ }^{10}$; as well as of multitude of humanitarian organizations of varying size and experience. UNHCR, which was designate to lead and co-operate the tasks of different actors, encouraged, but could not compel any of them to take the directions (Mockaitis, 2004b: 45). Larry Minear and others (Minear, Baarda, Sommers, 2000), as well as Thomas Mockaitis (Mockaitis, 2004) present comprehensive studies on the civil-military relations during Kosovo operation. Analysing the lessons learned from these experiences, we can present the list of important issues that should be a basis for better training and preparation for future interventions.

9 For detail description of legality and legitimacy of the Kosovo intervention please refer to: Julie, Mertus, Reconsidering the Legality of Humanitarian Intervention: Lessons from Kosovo, "William and Mary Law Review" 2000, Vol. 41, pp. 1743-1787.

${ }^{10}$ While authorizing KFOR, the UN deployed its own, autonomous civilian UN Mission in Kosovo (UNMIK). 
First of all, military units and humanitarian organisations should participate in joint pre-missions to ensure greater cooperation in the field. Such training and education can break down mutual misunderstanding and mistrust, so that CIMIC, depended on the circumstances can be both a force multiplier for the military and an aid-delivery actor for the humanitarian community. What is more, exchange of reciprocal knowledge can also help to bridge the cultural gap between "the military's formal vertical organization and logistics-based approach to problem solving and the less formal, horizontal organization and pragmatic approach to problem solving of NGOs/IOs" (Mockaitis, 2004a: vii). Second, military intervention force, must be prepared to conduct police tasks until a working civil police can be established. The lack of ability to carry out such functions in the first months of the Kosovo mission invited lawlessness and revenge. Third, the time of duty for military troops should be standardized at no less than 6 months, and should overlap to allow the replacement unit to learn from the previous one about the local situation. Fourth, as the NGOs/IOs frequently complain that military units ask them to share information but are unwilling to share information with the humanitarians, military units should re-evaluate their rules for classifying information.

The above presented issues are not exhaustive, but present a spectrum of complexity with which civilian and military actors must have coped with during intervention in Kosovo. It also gives a foundation for further development of the cooperation and management between the two parties.

\section{CIVIL-MILITARY HUMANITARIAN INTERVENTION - PROSPECTS FOR FUTURE}

One of the recent propositions for overcoming the difficulties concerning civil-military relations in humanitarian interventions was the proposal of transnational coalition of civil society organisations, to establish United Nations Emergency Peace Service (UNEPS), which would be nothing else as rapid response force within the UN. Designed as permanent body, based at UN and including mobile field headquarters, it could move to face an emergency within 48 hours after United Nations authorisation. Its main advantage would consist in carefully selected, expertly trained and coherently organized and commanded staff, including civilian, police, judicial and military personnel, prepared to conduct multiple functions in diverse UN operations. In the words of the authors of the proposal "by providing a wide range of functions, the UN Emergency Peace Service would, for the first time in the history, offer a rapid, comprehensive, internationally legitimate response to crisis" (Johansen, 2006: 22). Although the concept itself is interesting and already has been developed by different actors on the political agenda, the international consensus for creating civil-police-military forces of the United Nations will need much more time and efforts to be reached.

\section{$* * *$}

Concept of humanitarian intervention has significantly developed in the last century, transforming from the right of a country to lead a just war into the responsibility of 
a state to provide security for its citizens. The promotion of UN principles such as human rights, development of civil societies and a growing number of civil actors involved in the conflict situations made the issue of cooperation between civil and military actors crucial for the success of the operation. 1990s have witnessed the unprecedented number and scope of humanitarian interventions, as a reaction for gross human rights violations that begun after the end of the Cold War. Successes and failures from this operations gave the international community important guidelines to improve its future reactions to various atrocities against humans.

First decade of $21^{\text {st }}$ century was labelled with the 'war on terror', and US interventions in Afghanistan and Iraq. For both of these operations, despite clear main reasons for intervention, US claimed also humanitarian aspects in their argumentation. Although US did not receive authorization for their Iraq intervention, there remained a discontent about misusing the somehow noble idea of humanitarian intervention for power-states own interest and strategy.

On the other hand, the use of the Responsibility to Protect tool in case of Libya in 2011 is for many scholars and politicians controversial and questionable issue.

All of these developments show clearly, how complicated and politicized the issue of humanitarian intervention is. And all of that makes the civil-military relations often even tougher to manage. Nevertheless, the continuous analysing and learning process as well as new approaches in training and cooperation between civil and military sets of institutions will certainly bring better results in future operations.

\section{Bibliography}

Brown A. (2008), Reinventing Humanitarian Intervention: Two Cheers for the Responsibility to Protect, House of Commons Library, Research Paper 08/55, http://www.parliament.uk/briefing-papers/RP08-55 (2.09.2013).

Charter of the United Nations and the Statute of the International Court of Justice (1945), New York.

Civil-Military Guidelines \& Reference for Complex Emergencies (2008), Inter-Agency Standing Committee, New York, http://www.unhcr.org/refworld/docid/47da82a72.html (20.09.2012).

Evans G. (2006), From Humanitarian Intervention to the Responsibility to Protect, "Wisconsin International Law Journal", Vol. 24, No. 3.

Finnemore M. (1996), Constructing Norms of Humanitarian Intervention, in: The Culture of National Security: Norms and Indentity in World Politics, (ed.) P. J. Katzenstein, New York.

Gourlay C. (2000), Partners Apart: Managing Civil-Military Co-operation in humanitarian Interventions, "Disarmament Forum Peacekeeping Evolution or Extinction?", No. 3, http://www.unidir.org/pdf/articles/pdf-art131.pdf (15.09.2013).

Guidelines on the Use of Military and Civil Defence Assets in Disaster Relief (2006), http://reliefweb.int/sites/reliefweb.int/files/resources/8706B7B69BD77E00C1257233004F0570-OCHA-Nov2006.pdf (18.09.2013).

Holzgrefe J. L. (2003), Humanitarian intervention debate, in: Humanitarian Intervention, Ethical, Legal and Political Dilemmas, (eds.) J. L. Holzgrefe, R. O. Keohane, Cambridge.

Implementing the responsibility to protect. Report of the Secretary-General (2009), United Nations General Assembly, http://globalr2p.org/pdf/SGR2PEng.pdf (20.09.2012). 
Implementing the Responsibility to Protect. The 2009 General Assembly Debate: An Assessment (2009), Global Centre for the Responsibility to Protect, GCR2P_General_Assembly_Debate_Assessment.pdf (20.09.2012).

Johansen R. C. (2006), A United Nations Emergency Peace Service: To prevent Genocide and Crimes against Humanity, New York.

Kak K. (2008), Humanitarian intervention and the changing role of the UN, "Strategic Analysis", Vol. 24, No. 7.

Kardas S. (2001), Humanitarian Intervention: The evolution of the idea and practice, "Perceptions Journal of International Affairs", Vol. 4, No. 2.

Kundsen T. B. (1997), Humanitarian Intervention Revisited: Post-Cold War Responses to Classical Problems, in: The UN, Peace and Force, (ed.) M. Pugh, London.

Mazarr M. J. (1993), The Military Dilemmas of Humanitarian Intervention, "Security Dialogue", Vol. 24, No. 2.

Mertus J. (2000), Reconsidering the Legality of Humanitarian Intervention: Lessons from Kosovo, "William and Mary Law Review", Vol. 41.

Millennium Report of the Secretary-General of the United Nations, We the People: The Role of the United Nations in the $21^{\text {st }}$ Century (2000), United Nations Secretary General, http://www.un.org/ millennium/sg/report/ch3.pdf (20.09.2012).

Minear L., van Baarda T., Sommers M. (2000), NATO and Humanitarian Action in the Kosovo Crisis, Occasional Paper, No. 36.

Minear L., Guillot Ph. (1996), Soldiers to the Rescue: Humanitarian Lessons from Rwanda, Development Centre of the Organisation of Economic Co-operation and Development, http://www.grandslacs.net/ doc/1091.pdf (20.09.2012).

Mockaitis Th. R. (2004a), Civil-Military Cooperation in Peace Operations: The case of Kosovo, Strategic Studies Institute, http://www.strategicstudiesinstitute.army.mil/pdffiles/pub583.pdf (20.09.2012).

Mockaitis Th. R. (2004b), Reluctant Partners: Civil-Military Cooperation in Kosovo, "Small Wars \& Insurgencies", Vol. 15, No. 2.

NATO Civil-Military Co-operation (CIMIC) Doctrine (2000), AJP-9, http://www.nato.int/ims/ docu/ajp-9.pdf (20.09.2012).

Resolution 1674 of the UN Security Council (2006), http://www.un.org/News/Press/docs/2006/ sc8710.doc.htm (20.09.2012).

Roberts A. (1993), Humanitarian War: Military Intervention and Human Rights, "International Affairs", Vol. 69, No. 3.

Seybolt T. B. (2007), Humanitarian Military Intervention, The Conditions for Success and Failure, Oxford.

Slim H. (1996), The Stretcher and the Drum: Civil-Military Relations in Peace Support Operations, "International Peacekeeping", Vol. 3, No. 2.

Stahn C. (2002), Responsibility to Protect: Political Rhetoric or Emerging Legal Norm?, "The American Journal of International Law", Vol. 101, No. 99.

The Responsibility to Protect (2001), International Commission on Intervention and State Sovereignty, Ottawa.

Weiss T. G. (1995), Military - Civilian Humanitarianism: The Age of Innocence is Over, "International Peacekeeping", Vol. 2, No. 2.

2005 World Summit Outcome (2005), United Nations General Assembly, http://www.who.int/hiv/ universalaccess2010/worldsummit.pdf (20.09.2012). 


\begin{abstract}
The following essay describes the idea of humanitarian intervention in relation to civil-military cooperation. In the first part it presents the definition of the concept, its characteristics as well as the brief history of its development. Second part describes the issues of legality and legitimacy of humanitarian intervention. Third part concentrates on relations between civil and military actors, co-operation of their tasks based on the example of CIMIC, as well as the challenges remaining to make their coexistence successful. For better presentation of the complexity of the issue, in the last part are presented lessons learned from humanitarian intervention in Kosovo. Article ends with short presentation of future prospect for improvement of civil-military cooperation in humanitarian interventions.
\end{abstract}

\title{
INTERWENCJA HUMANITARNA. WYBRANE ASPEKTY
}

\section{STRESZCZENIE}

W artykule poruszono problem interwencji humanitarnej w relacji do współpracy cywilno-wojskowej. W pierwszej części zdefiniowano i scharakteryzowano omawianą koncepcję, przedstawiono także genezę jej rozwoju. W części drugiej zanalizowano kwestię legalności interwencji humanitarnej w świetle prawa międzynarodowego. W części trzeciej uwagę skoncentrowano na analizę: relacji między cywilnymi i wojskowymi aktorami; współpracy w wykonywaniu obowiązków na przykładzie CIMIC; a także wyzwań, którym należy sprostać, aby uczynić kooperację skuteczną. W ostatniej części zaprezentowano konsekwencje interwencji w Kosowie w 1999 r. 